\title{
Soybean Parent Selection Based on Genetic Diversity
}

\author{
Valéria Carpentieri-Pípolo*1, Antônio Eduardo Pípolo², Flávio André Martins da Silva ${ }^{3}$ \\ and Marcos Rafael Petek ${ }^{3}$ \\ ${ }^{1}$ Departamento de Agronomia da UEL, Caixa Postal 6001, CEP 86051-990, Londrina, PR. ${ }^{2}$ Embrapa Soja, Caixa \\ Postal 231, CEP 86001-970, Londrina, PR. ${ }^{3}$ Graduando em Engenharia Agronômica da UEL, Caixa Postal 6001, \\ CEP 86051-990, Londrina - PR, Brazil
}

\begin{abstract}
Thirty-four soybean lines were assessed for twelve traits. The genetic distances were estimates using multivariate techniques, to identify parents to be included in breeding programs for hybridization. Grouping by the Tocher method, from generalized Mahalanobis distances, divided the 34 lines into four groups. The most important agronomic traits, weight of seeds per plot, plant height, height of first pod and days to maturity were considered when recommending for crossing. The following crosses were recommended based on the genetic divergence and the key agronomic traits: lines 23, 10, 2, 27 and 25 (group I) with genotype 6 (group II) and genotype 16 (group III). Thus only ten crosses would be made, representing only $2 \%$ of the total crosses which could be made in the partial diallel among the 34 lines assessed, which would allow up to 561 combinations.
\end{abstract}

Key words: soybean, genetic divergence, Mahalanobis, multivariate analysis

\section{INTRODUCTION}

The most important step in a breeding program is the choice of parents with good performance and wide genetic base. Analysis of the parents' isolated behavior and the result of diallel crosses are options in the choice of parents. But the need to carry out a large number of artificial crosses and experiments involving a large number of hybrids limit the use of diallel crosses.

Thus measures of the genetic divergence, ahead of making any cross is made, may help breeders to concentrate their efforts only on the most promising combinations. Heterosis, manifested in the crosses, is directly related to genetic divergence among the parents (Falconer, 1981).

Destro (1991) observed that high $\mathrm{D}^{2}$ (Mahalanobis generalized distance) in soybean was not always associated with high yield, nevertheless, low $\mathrm{D}^{2}$ was generally associated with low yield. The best results were obtained in the crosses with intermediate $\mathrm{D}^{2}$. Therefore, in the choice of parents to be used in hybridization, emphasis should be placed both on the cultivars performance and on its genetic distances (Miranda et al., 1988; Cruz, 1990; Rangel et al, 1991; Destro, 1991).

Carvalho et al. (1995) used the genetic divergence method to access a diallel cross among seven cotton cultivars for resistance to ramulose (Colettotrichum gossypii var. cephalosporioides). Forty nine treatments were divided into seven groups and the traits such as plant height, fiber percentage and short cycle most contributed to divergence among the genotypes.

Pípolo et al. (1995) assessed the performance of 25 genotypes for eight traits to identify suitable parents for a guandu breeding program. The genotypes were divided into five groups and 24 crosses were recommended when the traits plant height, protein percentage and oil percentage were considered, $8 \%$ of the total possible crosses involving the 25 suitable genotypes.

Amaral Júnior et al. (1996) estimated the genetic divergence among eight strawberry genotypes and indicated the most promising combinations and described the most important morphoagronomic traits in the characterization of variability. Four 
groups were established by the Tocher method and four crossing combinations were recommended to widen the genetic base of the species.

Souza (1996) used enzymatic and agronomic data to estimate the genetic diversity among Caribbean cherry accessions. Seven enzymatic systems and six agronomic traits were observed to characterize the 16 Caribbean cherry accessions. The divergence estimates by enzymatic standards did not correlate significantly with the agronomic characteristics because the accessions grouped in four groups for the isozymatic systems and in only three for the agronomic traits. However, for breeding programs, two crossing combinations were recommended among three accessions because of the high genetic diversity found both in the isozymatic and the agronomic data.

This study was carried out to estimate the genetic divergence of 34 soybean lines to identify suitable parents for genetic breeding programs.

\section{MATERIAL AND METHODS}

Thirty-four soybean lines were accessed (Table 1) from the National Center for Soybean Research (Embrapa-Soja), The Agronomic Institute (IAC), CODETEC and FT - Pesquisa e sementes) at the Faculty of Agrarian and Veterinary Sciences, UNESP Jaboticabal, SP, during 1990.

A randomized complete block design was used with 34 treatments and three replications.
The plots were four $5 \mathrm{~m}$ rows, spaced $0.50 \mathrm{~m}$. The soil in the experimental area was classified as distrophic Dark Red Latossol with medium texture and fertility.

At harvest, stage R8 (Fehr \& Cavines 1977), 15 plants from two central rows of each plot were collected to determine the following agronomic traits: YP: yield per plot (g); PH: plant height $(\mathrm{cm})$; HFP: height of first pod $(\mathrm{cm})$; NPP: number of pods per plant; NP1G: number of pods with one grain; NP2G: number of pods with two grains; NP3G: number of pods with 3 grains; SD: stem diameter $(\mathrm{cm})$; SWB: stem weight plus bark $(\mathrm{g})$; WS: weight of a hundred seeds (g); DM: days to maturity (number of days from emergence to $90 \%$ ripe pods); DF: days to flowering (number of days from emergence to $90 \%$ open flowers).

In addition to the analyses of variance, multivariate analysis and comparison of measurements using the criteria proposed by Duncan, the following were also obtained: a) estimate of Mahalanobis generalized distance (1936); b) establishment of similar groups using the optimization method proposed by Tocher, quoted by Rao (1952) with a reduced example of this method presented by Singh \& Chaudhary (1977) and c) graphic analysis of divergence, using canonic variables. These procedures will supply information on genetic distance, by the scattering of the scores of each genotype in the cartesian system, whose axes are established by the first canonic pair (Rao, 1952). 
Table 1 - Means for 12 agronomic traits evaluated in 34 soybean lines.

\begin{tabular}{|c|c|c|c|c|c|c|c|c|c|c|c|c|}
\hline Lines & YP & $\mathrm{PH}$ & HFP & NPP & NP1G & $\mathrm{NP} 2 \mathrm{G}$ & NP3G & SD & SWB & WS & DF & $\mathrm{DM}$ \\
\hline 23. BR-88 40.242 & $3562.00 \mathrm{a}$ & $91.33 \mathrm{abc}$ & $16.66 \mathrm{abc}$ & $313.00 \mathrm{abc}$ & 103.66 abcde & $181.00 \mathrm{abc}$ & $28.33 \mathrm{abc}$ & 0.603 abcde & $3679.66 \mathrm{abc}$ & 24.33 abcdef & 46 & 123 \\
\hline 10. BR-88 40.152 & $3423.00 \mathrm{a}$ & $87.66 \mathrm{abcd}$ & $15.33 \mathrm{bc}$ & $291.66 \mathrm{abcd}$ & 130.00 abcde & $116.33 \mathrm{~cd}$ & $45.00 \mathrm{ab}$ & 0.527 cde & $3146.66 \mathrm{abcd}$ & 24.66 abcde & 50 & 131 \\
\hline 2. IAC-Foscarim & $3407.33 \mathrm{ab}$ & $87.66 \mathrm{abcd}$ & $20.00 \mathrm{abc}$ & $388.66 \mathrm{a}$ & 130.66 abcde & $211.66 \mathrm{ab}$ & $46.33 \mathrm{a}$ & 0.600 abcde & $4888.66 \mathrm{a}$ & 23.66 bcdefg & 51 & 126 \\
\hline 27. BR-88 40.354 & $3332.00 \mathrm{ab}$ & $85.00 \mathrm{abcd}$ & $14.00 \mathrm{bc}$ & $295.00 \mathrm{abcd}$ & 126.00 abcde & $133.33 \mathrm{abcd}$ & $35.66 \mathrm{abc}$ & 0.583 bcde & $3404.33 \mathrm{abcd}$ & 21.66 ghi & 49 & 124 \\
\hline 9. BR-88 40.150 & $3164.33 \mathrm{ab}$ & $87.33 \mathrm{abcd}$ & $14.33 \mathrm{bc}$ & $266.66 \mathrm{abcd}$ & 92.66 bcde & $146.33 \mathrm{abcd}$ & $27.66 \mathrm{abc}$ & 0.517 cde & $4461.66 \mathrm{abc}$ & 24.66 abcde & 52 & 129 \\
\hline 25. BR-88 40.255 & $3129.66 \mathrm{abc}$ & $89.00 \mathrm{abc}$ & $20.00 a b c$ & $285.33 \mathrm{abcd}$ & 139.00 abcde & $126.66 \mathrm{bcd}$ & $19.66 \mathrm{abc}$ & $0.450 \mathrm{de}$ & $2693.00 \mathrm{bcd}$ & $20.33 \mathrm{i}$ & 51 & 128 \\
\hline 1. IAC- 16 & $3113.00 a b c$ & 83.33 abcde & $12.66 \mathrm{bc}$ & $319.66 \mathrm{abc}$ & 136.66 abcde & $162.33 \mathrm{abcd}$ & $20.66 \mathrm{abc}$ & 0.523 cde & $3670.66 a b c$ & $26.00 \mathrm{ab}$ & 48 & 126 \\
\hline 14. BR-88 40.192 & $3081.00 \mathrm{abc}$ & 79.66 abcde & $20.00 \mathrm{abc}$ & $279.66 \mathrm{abcd}$ & 118.33 abcde & $135.33 \mathrm{abcd}$ & $26.00 \mathrm{abc}$ & $0.443 \mathrm{de}$ & $3555.33 \mathrm{abcd}$ & $25.00 \mathrm{abcd}$ & 49 & 132 \\
\hline 22. BR-88 40.219 & $3030.66 \mathrm{abc}$ & $93.66 \mathrm{ab}$ & $15.33 \mathrm{bc}$ & $386.66 \mathrm{ab}$ & 114.33 abcde & $224.33 \mathrm{a}$ & $48.00 \mathrm{a}$ & $0.750 \mathrm{ab}$ & $4515.00 \mathrm{abc}$ & 22.66 defghi & 47 & 129 \\
\hline 12. BR-88 40.187 & $2969.66 \mathrm{abc}$ & $73.66 \mathrm{de}$ & $13.33 \mathrm{bc}$ & $336.00 \mathrm{abc}$ & 128.00 abcde & $174.00 \mathrm{abc}$ & $34.00 \mathrm{abc}$ & $0.710 \mathrm{abc}$ & $3928.66 \mathrm{abc}$ & 23.00 cdefgh & 50 & 124 \\
\hline 34. BR-88 40.103 & $2936.33 \mathrm{abc}$ & $88.66 \mathrm{abc}$ & $21.33 \mathrm{ab}$ & $320.66 \mathrm{abc}$ & 125.00 abcde & $164.33 \mathrm{abcd}$ & $31.33 \mathrm{abc}$ & 0.583 bcde & $3724.00 \mathrm{abc}$ & 22.00 fghi & 48 & 130 \\
\hline 8. BR-88 40.062 & $2919.66 \mathrm{abc}$ & $92.33 \mathrm{abc}$ & $19.00 \mathrm{abc}$ & $345.00 \mathrm{abc}$ & $157.00 \mathrm{ab}$ & $160.00 \mathrm{abcd}$ & $28.00 \mathrm{abc}$ & 0.587 bcde & $4764.00 \mathrm{ab}$ & 21.66 ghi & 50 & 130 \\
\hline 18. BR-88 40.204 & $2877.66 \mathrm{abc}$ & $87.33 \mathrm{abcd}$ & $17.66 \mathrm{abc}$ & $324.33 \mathrm{abc}$ & $141.66 \mathrm{abcd}$ & $153.66 \mathrm{abcd}$ & $29.00 \mathrm{abc}$ & 0.577 bcde & $3751.00 \mathrm{abc}$ & 23.33 cdefgh & 48 & 126 \\
\hline 19. BR-88 40.205 & $2849.66 \mathrm{abc}$ & 80.33 abcde & $20.66 \mathrm{ab}$ & $317.66 \mathrm{abc}$ & 110.00 abcde & $168.66 \mathrm{abc}$ & $39.00 \mathrm{abc}$ & 0.580 bcde & $3990.66 \mathrm{abc}$ & 21.6 & 49 & 128 \\
\hline 13. BR-88 40.189 & $2845.33 \mathrm{abc}$ & $89.33 \mathrm{abc}$ & $18.33 \mathrm{abc}$ & $360.00 \mathrm{ab}$ & $172.00 \mathrm{a}$ & $164.66 \mathrm{abcd}$ & $23.33 \mathrm{abc}$ & 0.597 abcde & $3635.33 a b c$ & $25.00 \mathrm{abcd}$ & 46 & 127 \\
\hline 26. BR-88 40.257 & $2817.33 a b c$ & 83.33 abcde & $16.33 a b c$ & $296.33 \mathrm{abcd}$ & 125.00 abcde & $145.33 \mathrm{abcd}$ & $26.00 \mathrm{abc}$ & 0.517 cde & $3768.33 a b c$ & 21.33 ghi & 49 & 127 \\
\hline 5. BR-88 40.055 & $2807.33 \mathrm{abc}$ & $70.00 \mathrm{e}$ & $18.66 \mathrm{abc}$ & $328.66 \mathrm{abc}$ & 113.33 abcde & $178.66 \mathrm{abc}$ & $36.66 \mathrm{abc}$ & 0.560 bcde & $3964.00 \mathrm{abc}$ & 23.00 cdefgh & 46 & 126 \\
\hline 29. BR-88 40.502 & $2807.33 \mathrm{abc}$ & 81.33 abcde & $25.66 \mathrm{a}$ & $269.66 \mathrm{abcd}$ & 109.00 abcde & $129.33 \mathrm{bcd}$ & $31.33 \mathrm{abc}$ & 0.543 cde & $4070.66 \mathrm{abc}$ & 22.33 efghi & 47 & 130 \\
\hline 24. BR-88 40.249 & $2733.00 \mathrm{abc}$ & $87.33 \mathrm{abcd}$ & $17.00 \mathrm{abc}$ & $295.00 \mathrm{abcd}$ & 128.00 abcde & $137.66 \mathrm{abcd}$ & $29.33 \mathrm{abc}$ & $0.550 \mathrm{cde}$ & $1550.33 \mathrm{~d}$ & ghi & 51 & 130 \\
\hline 4. FT-Cometa & $2699.66 \mathrm{abc}$ & 78.00 cde & $21.33 \mathrm{ab}$ & $297.66 \mathrm{abcd}$ & 136.66 abcde & $135.66 \mathrm{abcd}$ & $25.33 \mathrm{abc}$ & 0.560 bcde & 3475.33 abcd & 23.66 bcdefg & 47 & 125 \\
\hline 6. BR-88 40.057 & $2628.66 \mathrm{abc}$ & $90.33 \mathrm{abc}$ & $12.33 \mathrm{bc}$ & $201.66 \mathrm{~cd}$ & 81.33 cde & $98.33 \mathrm{~cd}$ & $22.00 \mathrm{abc}$ & $0.423 \mathrm{e}$ & $2479.66 \mathrm{~cd}$ & $26.00 \mathrm{ab}$ & 49 & 130 \\
\hline 20. BR-88 40.210 & $2596.33 \mathrm{abc}$ & 81.33 abcde & $15.00 \mathrm{bc}$ & $294.66 \mathrm{abcd}$ & $153.00 \mathrm{abc}$ & $110.00 \mathrm{~cd}$ & $31.66 \mathrm{abc}$ & 0.560 bcde & $3884.00 \mathrm{abc}$ & $26.33 \mathrm{a}$ & 48 & 130 \\
\hline 7. $\mathrm{BR}-8840.058$ & $2568.66 \mathrm{abc}$ & 81.00 abcde & $18.33 \mathrm{abc}$ & $284.33 \mathrm{abcd}$ & 123.00 abcde & $122.66 \mathrm{bcd}$ & $38.66 \mathrm{abc}$ & 0.593 abcde & $3359.66 \mathrm{abcd}$ & 22.66 defghi & 49 & 131 \\
\hline 33. BR-88 40.052 & $2553.00 \mathrm{abc}$ & $94.00 \mathrm{a}$ & $21.33 \mathrm{ab}$ & $256.33 \mathrm{abcd}$ & 109.66 abcde & $114.00 \mathrm{~cd}$ & $32.66 \mathrm{abc}$ & $0.550 \mathrm{cde}$ & $2897.33 \mathrm{abcd}$ & 22.66 defghi & 46 & 130 \\
\hline 32. BR-88 40.013 & $2426.33 a b c$ & $87.33 \mathrm{abcd}$ & $15.33 \mathrm{bc}$ & $238.33 \mathrm{bcd}$ & $80.00 \mathrm{de}$ & $116.33 \mathrm{~cd}$ & $42.00 \mathrm{abc}$ & 0.620 abcde & $3857.33 a b c$ & 23.66 bcdefg & 49 & 130 \\
\hline 21. BR-88 40.217 & $2400.66 \mathrm{abc}$ & 81.66 abcde & $17.66 \mathrm{abc}$ & $303.66 \mathrm{abcd}$ & 105.00 abcde & $155.66 \mathrm{abcd}$ & $44.66 \mathrm{ab}$ & 0.523 cde & $4746.33 \mathrm{ab}$ & 24.33 abcdef & 49 & 130 \\
\hline 28. BR-88 40.407 & $2348.66 \mathrm{abc}$ & $88.00 \mathrm{abcd}$ & $15.33 \mathrm{bc}$ & $267.33 \mathrm{abcd}$ & 135.66 abcde & $111.33 \mathrm{~cd}$ & $20.33 \mathrm{abc}$ & 0.553 cde & $3608.66 \mathrm{abc}$ & 21.33 ghi & 49 & 120 \\
\hline 17. BR-88 40.202 & $2324.00 \mathrm{abc}$ & 79.33 bcde & $17.33 \mathrm{abc}$ & $242.00 \mathrm{abcd}$ & 106.33 abcde & $103.33 \mathrm{~cd}$ & $32.33 \mathrm{abc}$ & 0.567 bcde & $3857.66 \mathrm{abc}$ & 22.33 efghi & 44 & 132 \\
\hline 15. BR-88 40.197 & $2276.33 \mathrm{abc}$ & $88.66 \mathrm{abc}$ & $17.66 \mathrm{abc}$ & $280.33 \mathrm{abcd}$ & 133.00 abcde & $117.00 \mathrm{~cd}$ & $30.33 \mathrm{abc}$ & $0.450 \mathrm{de}$ & $4319.66 \mathrm{abc}$ & 22.33 efghi & 48 & 130 \\
\hline 16. BR-88 40.199 & $2264.33 \mathrm{abc}$ & $88.33 \mathrm{abc}$ & $17.66 \mathrm{abc}$ & $279.33 \mathrm{abcd}$ & 123.33 abcde & $155.33 \mathrm{abcd}$ & $37.33 \mathrm{abc}$ & 0.513 cde & $4186.33 \mathrm{abc}$ & $21.00 \mathrm{hi}$ & 48 & 130 \\
\hline 30. BR-88 40.002 & $2109.66 \mathrm{bcd}$ & 81.33 abcde & $14.00 \mathrm{bc}$ & $304.00 \mathrm{abcd}$ & 132.00 abcde & $141.66 \mathrm{abcd}$ & $30.33 \mathrm{abc}$ & $0.623 \mathrm{abcd}$ & $3093.00 \mathrm{abcd}$ & $26.00 \mathrm{ab}$ & 47 & 131 \\
\hline 31. BR-88 40.007 & $1833.00 \mathrm{~cd}$ & 80.33 abcde & $16.33 \mathrm{abc}$ & $154.66 \mathrm{~d}$ & $67.66 \mathrm{e}$ & $73.00 \mathrm{~d}$ & $14.00 \mathrm{bc}$ & $0.513 \mathrm{cde}$ & $2542.00 \mathrm{~cd}$ & 23.00 cdefgh & 51 & 126 \\
\hline 3. Ocepar-3 & $1827.33 \mathrm{~cd}$ & $78.00 \mathrm{cde}$ & $10.33 \mathrm{c}$ & $291.66 \mathrm{abcd}$ & $171.00 \mathrm{a}$ & $104.00 \mathrm{~cd}$ & $16.66 \mathrm{abc}$ & $0.780 \mathrm{a}$ & $3288.66 \mathrm{abcd}$ & 23.00 cdefgh & 47 & 131 \\
\hline 11. BR-88 40.174 & $1032.33 \mathrm{~d}$ & $93.00 \mathrm{ab}$ & $18.00 \mathrm{abc}$ & $263.66 \mathrm{abcd}$ & 116.66 abcde & $135.33 \mathrm{abcd}$ & $11.66 \mathrm{c}$ & $0.550 \mathrm{cde}$ & 3244.00 abcd & $25.33 a b c$ & 48 & 130 \\
\hline
\end{tabular}

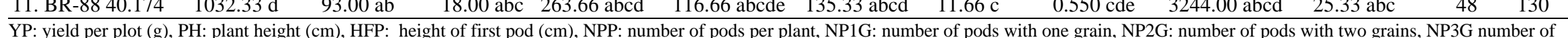
pods with 3 grains, SD stem diameter $(\mathrm{cm})$, SWB stem weight plus bark (g), WS: weight of a hundred seeds (g), DF: flowering (days), DM: days to maturity (days). 


\section{RESULTS AND DISCUSSION}

Table 2 shows that there are significant differences among the means of the 34 soybean lines for all the traits. The genotypic determination coefficients (b) for the traits YP, PH, SD and WS have values greater than $30 \%$, suggesting the possibility of fairly efficient discrimination of superior parental genotypes among the 34 assessed lines. Except for HFP, NP1G, NP2G, NP3G and SWB with a high C.V. of over $30 \%$, the C.V. of the other traits varied from $6,27 \%$ to $28,35 \%$ in acceptable experimental accuracy levels for field experiments.

Table 2 - Analysis of variance for ten traits in 34 soybean genotypes, with the respective means, variation coefficient (C.V.) and genotypic determination (b), in Jaboticabal, SP, 1990.

\begin{tabular}{|c|c|c|c|c|c|c|c|c|c|c|c|}
\hline \multicolumn{12}{|c|}{ Mean Square* } \\
\hline $\begin{array}{l}\text { Sources of } \\
\text { Variation }\end{array}$ & $\mathrm{df}$ & YP & $\mathrm{PH}$ & HFP & NPP & NP1G & $\mathrm{NP} 2 \mathrm{G}$ & NP3G & SD & SWB & WS \\
\hline Plots & 2 & 1028578,41 & 74,954 & 11,186 & 31,294 & 76,713 & 1711,92 & 547,54 & 0,0323 & 2883637 & 6,303 \\
\hline Genotype & 33 & 797857,37 & $98,978^{*}$ & 29,418 & 6346,11 & 1597,23 & 3071,91 & 247,51 & 0,01741 & 481320 & $7,908^{*}$ \\
\hline Residues & 66 & 523140,66 & 63,314 & 30,762 & 6873,43 & 1613,90 & 2749,54 & 302,73 & 0,0120 & 1335686 & 2,132 \\
\hline Means & & 2696,92 & 84,97 & 17,19 & 293,51 & 122,78 & 141,39 & 30,45 & 0,56 & 3647,11 & 23,27 \\
\hline C.V.(\%) & & 26,82 & 9,36 & 32,27 & 28,25 & 32,72 & 37,09 & 57,14 & 19,46 & 31,69 & 6,27 \\
\hline $\mathrm{b}(\%)$ & & 34,43 & 36,03 & 0,00 & 0,00 & 0,00 & 10,49 & 0,00 & 30,81 & 9,83 & 73,04 \\
\hline
\end{tabular}

*significant at $1 \%$ probability by the $\mathrm{F}$ test

YP: yield per plot (g); PH: plant height (cm); HFP: height of first pod (cm); NPP: number of pods per plant; NP1G: number of pods with one grain; NP2G: number of pods with two grains; NP3G number of pods with 3 grains; SD stem diameter (cm); SWB stem weight plus bark (g); WS: weight of a hundred seeds $(\mathrm{g})$

The Tocher grouping method (quoted by Rao, 1952) from the Malhalanobis generalized distances $\left(\mathrm{D}^{2}\right)$ enabled the division of the 34 lines into four groups (Fig.1). Group I contained 30 genotypes, corresponding to $88.24 \%$ of the studied genotypes; group II contained 2 genotypes, corresponding to $5.88 \%$ and groups III and IV were made up of one genotype each, representing $2,94 \%$ of the lines. The BR-88 40.058 (7) and BR8840.202 (17) were the most closely related genetically as they had the smallest distance between them $\left(D^{2}=1,0901\right)$. The most genetically divergent genotypes were BR-88 40.057 (6) and BR-898 40.199 (16).

Many authors have recommended the use of parents with the greatest possible divergence to maximize the heterosis shown in the hybrids, increase the probability of superior segregants in advanced generations and widen the genetic base. Therefore, the information in Fig.1 should be used for cross recommendation. Using the multivariate statistic as a base, a high degree of similarity could be expected to be found among the genotypes belonging to the same group. Thus crosses within the same group should be avoided (Destro, 1991).The identification of genotypes based on genetic divergence, without considering their behavior, may not be a good strategy for a breeding program. Crosses among divergent genotypes that have a superior performance for the main characteristics of agronomic importance seem to be more recommended for breeding programs.

Three of the twelve traits studied in soybean breeding were especially important: WS, $\mathrm{PH}$ and DM. The WS trait was considered as representing the yield for each genotype in the plot, and genotypes with yield greater than $2500 \mathrm{~kg}$ hha were selected. The PH, HFP and DM traits were considered by their importance to quantify the adaptation of the genotypes to the region; the earliest were selected with a cycle up to 130 days and with plant height above $80 \mathrm{~cm}$ and first pod height above $15 \mathrm{~cm}$. Based on the established criteria (Table 1) the genotypes which stood out were $23,10,2,9$ and 25 , although genotype 27 had HFP of $14,00 \mathrm{~cm}$, it was also selected due to if its short cycle (120 day cycle). Fig. 1 shows these genotypes as belonging to group I, where the divergences can be seen graphically.

Genotypes number 6 with 2.628,66 kg/ha, PH $90,33 \mathrm{~cm}$, HFP $12,33 \mathrm{~cm}$ and DM 128 days 
belonging to group II and the genotype number 16 with $2.264,33 \mathrm{~kg} / \mathrm{ha}$, PH 88,33, HFP $17,66 \mathrm{~cm}$ and DM 127 days (Table 1, Fig. 1) were selected for their agronomic qualities.

Both the conglomeration technique based on Mahalanobis generalized distance and the analysis of the canonic variables were used for the quantification of the genetic divergence among the parents. In the latter, the genetic divergence was assessed by the graphic scattering of the scores for the studied genotypes on cartesian axes (Fig. 1). Generally researchers have opted for graphic representation when the first two canonic variables are greater than $70 \%$ of total available variability (Cruz 1990).

In this study, the dispersion in Fig. 1 was made for the two first canonic variables, which explain $75 \%$ of the total variation, which was satisfactory for this study. Table 1 shows the means of the 34 soybean lines in the 12 traits studied.

The yield values of the genotypes in Table 1 showed that the greatest yields occurred in more plants with pods with two grains (NP2G) and not in plants which had a greater total number of pods (NPP), a greater number of pods with 3 grains (NP3G) and nor a greater weight per hundred seeds (WS). Table 1 further showed that the stem diameter values (SD) varied from $0,432 \mathrm{~cm}$ to $0,870 \mathrm{~cm}$, which was more favorable because lower values caused less wear on machinery during harvest. The values of the stem plus bark varied from $1.550,33 \mathrm{~g}$ to $488,66 \mathrm{~g}$ the varieties with higher SWB values covered the soil more adequately and produced more green material.

The most important agronomic traits were recommended in the crosses, that is, yield per plot (YP), plant height $(\mathrm{PH})$, height of the first pod (HFP) and days to maturity (DM). The following crosses were recommended based on the genetic divergence and on the key agronomic traits: genotypes 23, 10, 2, 27 and 25 (group I) with genotype 6 (group II) and genotype 16 (group III). Thus, only ten crosses would be made, representing only $2 \%$ of the possible total in a partial diallel among the 34 lines assess, which would result in up to 561 combinations.

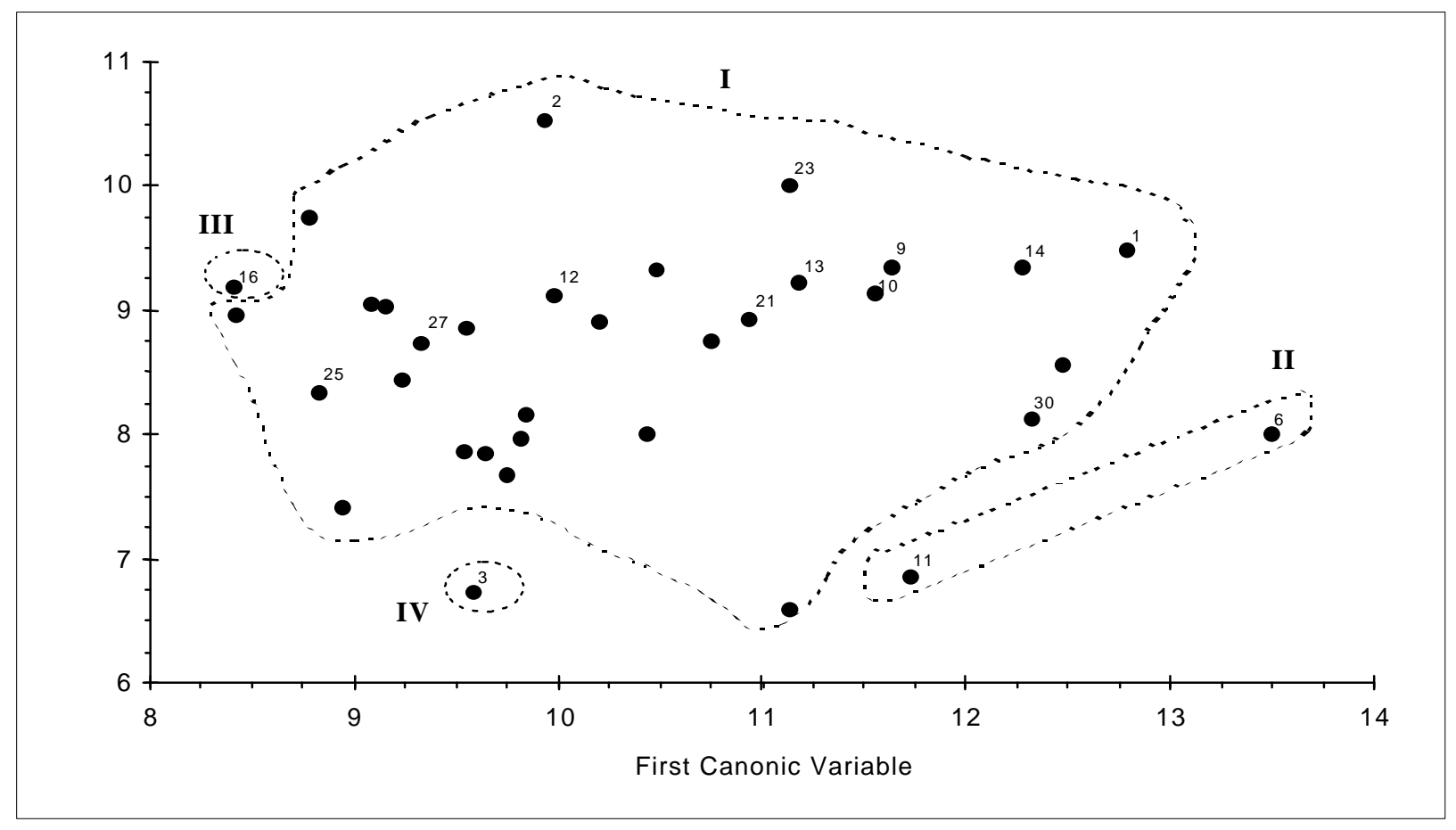

Figure 1 - Score scattering of the 34 soybean genotypes for the first two canonic variables. 


\section{RESUMO}

Trinta e quatro linhagens de soja foram avaliadas para doze características. As distâncias genéticas foram estimadas utilizando técnicas multivariadas com objetivo de identificar parentais a serem incluidos em um programa de melhoramento envolvendo hibridação. $\mathrm{O}$ agrupamento pelo método de Tocher, a partir das distâncias generalizadas de Mahalanobis, dividiu as 34 linhagens em 4 grupos. As caracterísiticas agronômicas mais importantes, peso de sementes por parcela, altura de planta, altura da primeira vagem e dias para maturação foram consideradas para a recomendação dos cruzamentos. Os seguintes cruzamentos foram recomendados baseado na divergência genética e nas características agronômicas chave: linhagens 23, 10, 2, 27 e 25 (grupo I) com genótipo 6 (grupoII) e com o genótipo 16 (grupo III). Portanto somente 10 cruzamentos poderiam ser realizados representando somente $2 \%$ do total de cruzamentos qu poderiam ser realizados em um dialelo parcial entre as 34 linhagens avaliadas as quais admitiriam até 561 combinações.

\section{REFERENCES}

Amaral Júnior, A.T.; Casali, V.W.D.; Cruz, C.D.; Finger, F.L. (1996), Utilização de variáveis canônicas e de análise de agrupamentos na avaliação da divergência genética entre acesso de moranga. Horticultura Brasileira, Brasília, 14, 2, 182-184.

Carvalho, L.P.; Cruz, C.D.; Moraes, C.F. (1995) Genetic divergence in Brazilian cotton, Gossypium hirsutum var. latifolium Hutch. Revista Brasileira de Genética, Ribeirão Preto, 18, 3, 439-443.
Cruz, C.D. (1990) Aplicações de algumas técnicas multivariadas no melhoramento de plantas. Piracicaba: ESALQ/USP, 188, Tese de Doutorado.

Destro, D. (1991) Capacidade de combinação de genótipos de soja (Glycine max (L.) Merrill) apropriados para o consumo humano. Piracicaba: ESALQ/USP, 158. Tese de Doutorado.

Falconer, D.S. (1981) Introduction to quantitative genetics. 2.ed. London: Longman, 340.

Fehr, W.R.; Cavines, C.E. (1977) Stages of soybean development. Ames, Iowa: State University of Science and Technology.

Mahalanobis, P.C. (1936) On the generalized distance in statistics. Proceedings National Institute of Science, 2, 49-55.

Miranda, J. E. C.; Cruz, C.D.; Costa, C.P. (1998) Predição do comportamento de híbridos de pimentão (Capsicum annuum, L.) pela divergência genética dos progenitores. Revista Brasileira de Genética, 11, 929937.

Pípolo, V.C.; Pípolo, A.E.; Destro, D.; Guerra, E.P. (1995) Seleção de genótipos de guandu baseada na divergência genética multivariada. Pesquisa Agropecuária Brasileira, Brasília, 30, 7, 977-982.

Rangel, P.H.N.; Cruz, C.D.; Vencovski, R.; Ferreira, R.P. (1991) Selection of local lowland rice cultivars based on multivariante genetic divergence. Revista Brasileira de Genética, 14, 2, 437-453.

Rao, R.C. (1952) Advanced statistical methods in biometric research. New York: John Wiley and Sons, 390.

Singh, R.K.; Chaudhary, B.D. (1977) Biometrical methods in quantitative genetic analysis. New Delhi: Kalyani Publ., 303.

Souza, J.C. (1996) Diversidade Genética entre acessos de acerola (Malpighia sp.) com base em dados isoenzimáticos e agronômicos, Viçosa:UFV, 67, Tese de Mestrado.
Received: April 05, 1999; Revised: July 01, 1999; Accepted: October 06,1999. 